REGARDS

SUR L'ECONOMIE ALLEMAND

BULLETIN ECONOMIQUE DU CIRAC
Regards sur l'économie allemande

Bulletin économique du CIRAC

116-117| 2015

Varia

\title{
Financement du Mittelstand
}

\section{(2) OpenEdition}

1 Journals

Édition électronique

URL : http://journals.openedition.org/rea/4850

DOI : $10.4000 /$ rea. 4850

ISSN : 1965-0787

Éditeur

CIRAC

Édition imprimée

Date de publication : 1 juillet 2015

Pagination : 76

ISSN : 1156-8992

\section{Référence électronique}

«Financement du Mittelstand», Regards sur l'économie allemande [En ligne], 116-117| juillet 2015, mis en ligne le 01 juillet 2015, consulté le 22 septembre 2020. URL : http://journals.openedition.org/rea/ 4850 ; DOI : https://doi.org/10.4000/rea.4850

Ce document a été généré automatiquement le 22 septembre 2020.

(c) CIRAC 


\section{Financement du Mittelstand}

\section{RÉFÉRENCE}

CUNY DE LA VERRIÈRE Antoine R., Le financement Schuldschein. Analyse d'un financement alternatif allemand en plein essor, Coll. Cahiers financiers, Groupe Larcier, Bruxelles, 2014, $302 \mathrm{p}$.

Finanzgruppe Deutscher Sparkassen- und Giroverband, Diagnose Mittelstand 2015 Kreditfinanzierung vor Kapitalmarkt, Deutscher Sparkassen- und Giroverband, Berlin, 2015, $67 \mathrm{p}$.

1 En Allemagne, les caisses d'épargne jouent un rôle clé dans le financement des PME (voir les articles de K.-P. Schackmann-Fallis dans REA 88/2008, 101/2011 et 108/2013). Dès lors, leur fédération (Deutscher Sparkassen- und Giroverband) publie depuis 2002 une étude annuelle sur le Mittelstand, reposant à la fois sur les bilans des entreprises clientes et sur l'expertise des chargés de clientèle au sein des caisses d'épargne. Parmi les principales conclusions de l'édition 2015 : une hausse de la part des fonds propres des PME, qui atteint la valeur record de $22,3 \%$, une réticence à investir de la part des entrepreneurs et une préférence persistante pour le crédit bancaire classique. Une autre source de financement très prisée, mais qui n'est pas l'objet de cette étude du DSGV, est le "Schuldschein", une forme de prêt quasi obligataire ou de "crédit syndiqué », auquel est consacré ce précis de droit financier. Les PME ne recourent que depuis le début du siècle, mais de façon croissante, à ce mode de financement développé à l'origine par les collectivités territoriales. (Isabelle Bourgeois/Solène Hazouard) 